\title{
A Case Study of ESL Students' Remote Speaking Class Learning Experiences in a Canada University During the COVID-19 Pandemic
}

\author{
Min Huang 8 (D) \\ PhD candidate, Joint-Educational Studies, Brock University, St Catharines, Ontario, Canada \\ $\triangle$ Corresponding Author: Min Huang, E-mail: mhuang7@outlook.com
}

\begin{tabular}{|c|c|}
\hline ARTICLE INFORMATION & ABSTRACT \\
\hline Received: April 01, 2021 & \multirow{7}{*}{$\begin{array}{l}\text { The COVID-19 pandemic forced a transfer from face-to-face (F2F) learning to remote } \\
\text { online learning in universities worldwide. A university in southern Ontario delivered } \\
\text { English courses to language learners living globally. This study, adopting a photo- } \\
\text { production visual method, explored four English as a second language (ESL) students' } \\
\text { perceptions of this online learning compared to typical F2F learning and investigated } \\
\text { activities enabling speaking opportunities and students' expectations for online } \\
\text { learning. The results showed that students perceived minor differences between } \\
\text { online learning and F2F learning, including a non-academic English environment, a } \\
\text { sense of community, and instant communications. The learning process involved } \\
\text { interactive and collaborative discussions and presentations that allow students' } \\
\text { speaking opportunities. The online discussions contributed to students' confidence } \\
\text { but lacked adequate feedback towards students' speaking skills. Students expected } \\
\text { more types of learning activities that contribute to collaborations among peers, a } \\
\text { sense of belonging to the online community, and examination orientated English } \\
\text { skills. }\end{array}$} \\
\hline Accepted: May 22, 2021 & \\
\hline Volume: 3 & \\
\hline Issue: 5 & \\
\hline DOI: 10.32996/jeltal.2021.3.5.4 & \\
\hline KEYWORDS & \\
\hline $\begin{array}{l}\mathrm{ESL} \text {; online learning; emergency } \\
\text { remote teaching; interaction; } \\
\text { collaboration }\end{array}$ & \\
\hline
\end{tabular}

\section{Introduction}

Since the outbreak of COVID-19 in 2020, universities in many countries worldwide took immediate actions to transfer classes online. This solution was to practice social distance and prevent the spread of the pandemic, resulting in an unprecedented period of emergency remote teaching (Hodges et al., 2020; Schlesselman, 2020). The transfer to online teaching required universities to take information communication technology approaches for instruction from a distance. During this global-scale crisis, emergency remote teaching (ERT) as a temporary solution to education took place in various locations worldwide.

Universities in Canada also took the action of a sudden transition from F2F classrooms to virtue classrooms, resulting in a historically unique activity: "quaranteaching" (Pace et al., 2020). A university in southern Ontario started to deliver online classes for English learners living in Canada and worldwide and became one of the only institutions among universities in Canada to do so (Morrison, 2020). ESL students seek language support from this program to acquire language skills and further academic development in Canada. The program was delivered mainly through Microsoft Teams and Sakai, the online learning platforms of this university, to ESL students living in Canada and globally.

Improving English-speaking skills for ESL learners is not merely essential for meeting enrollment requirements into universities; it is central to communication and language learning (Barron \& Zeegers, 2006; Haley \& Austin, 2004; Senyshyn et al., 2000; Uztosun et al., 2018). Speaking English remains the most challenging skill for some ESL learners (Ahn \& Lee, 2016; Kassem, 2018; Nguyen et al., 2018) and requires the development of appropriate activities to match students' needs and interests (Uztosun et al., 2018). It is essential to provide students with opportunities to practice speaking for attaining learning effectiveness (Haley \& Austin, 2004; Uztosun et al., 2018). Particularly, engaging students is critical to prevent them from dropping off from ESL programs (Alderete-Diez et al., 2012; Ghaith \& Shaaban, 2005). Despite the novel studies that provide suggestions for online

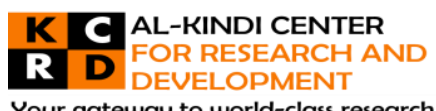

Your gateway to world-class research

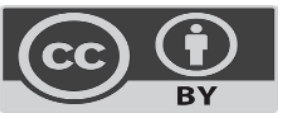

Published by Al-Kindi Center for Research and Development, United Kingdom. Copyright (c) the author(s). This open access article is distributed under a Creative Commons Attribution (CC-BY) 4.0 license 
engagement (e.g., Pace et al., 2020; Zayapragassarazan, 2020), there is limited empirical research investigating ESL students' engagement in remote speaking classes in the time of COVID-19. With the emergence of this disaster, it is imperative to rapidly examine the impact on and needs of students for decision-making in higher education programs (Fay \& Ghadimi, 2020; Slick, 2020). The priorities for investigation are whether or not students have enough opportunities to speak English and what students' needs are in this transition to online learning.

Researchers regarded online learning since the outbreak of COVID-19 as temporary access to learning and a replacement of physical classes. Existing research has investigated students' overall experiences of online education (Bozkurt et al., 2020; Dhawan, 2020; Mohmmed et al., 2020; Shim \& Lee, 2020; Sun et al., 2020) or in several English specific contexts, such as EFL studies in China (Huang et al., 2021) and ESL in Indonesia (Kholis, 2020). However, there are limited reports on ESL students' engagement in speaking classes in Canada. This study is a case study investigating ESL students' engagement in online speaking classes during the COVID-19 pandemic in Canada. This study will answer the following three research questions:

(1) What are ESL students' perceptions of online learning compared to F2F classes?

(2) What are the designs or activities that provide speaking opportunities and enhance speaking skills?

(3) What are ESL students' expectations of activities in online teaching?

\section{Literature review}

\subsection{Online Learning}

Online learning, also named distance learning or e-learning, has been studied for decades. It was defined as a learning experience of synchronous or asynchronous learning approaches or a combination of both using devices that have internet connections (Lotfi \& Pozveh, 2019; Singh \& Thurman, 2019). Synchronous learning allows real-time communication between students and instructors, resemble a conventional F2F learning situation. This model of learning usually consists of video/audio conferences and instant messaging through cameras and microphones. The use of synchronous learning approaches enhances student engagement, supports group identity, and enables timely feedback from instructors (Brown et al., 2016; Clouder et al., 2006; Falloon, 2011). In asynchronous learning, instead of meeting virtually in real-time, learners go through the learning process at their convenience of time and location (Moore, 2016). Web 2.0 allows content delivery through the internet and multiple directions of information exchanges, enabling a combination of both types of learning, allowing real-time communication and the flexibility of completing learning tasks according to students' schedules.

Developed from a constructivist perspective, the model constructed by Anderson carries the potential elements for successful online learning, highlighting the relationship between student and teacher and four types of learning lenses (Picciano, 2017). In this model (see Figure 1), Anderson (2011) emphasized the four overlapping lenses: learner, knowledge, assessment, and community that contribute to interactive online learning. The typologies of interactions, namely student-student, studentteacher, student-content, teacher-content, content-content, teacher-teacher interactions, serve as the basis of the instructional process of online learning. Within this learning community, teachers organize and initiate cooperative activities, promote dialogues among learners, and provide learning guidance (Cohen \& Holstein, 2018; Esteves et al., 2011; Minocha et al., 2011; Moradi et al., 2018; Sebbowa \& Muyinda, 2018; Wei, 2014), thus engaging community members in the meaningful learning process and accomplishing academic goals.

Figure 1: Anderson's online learning model

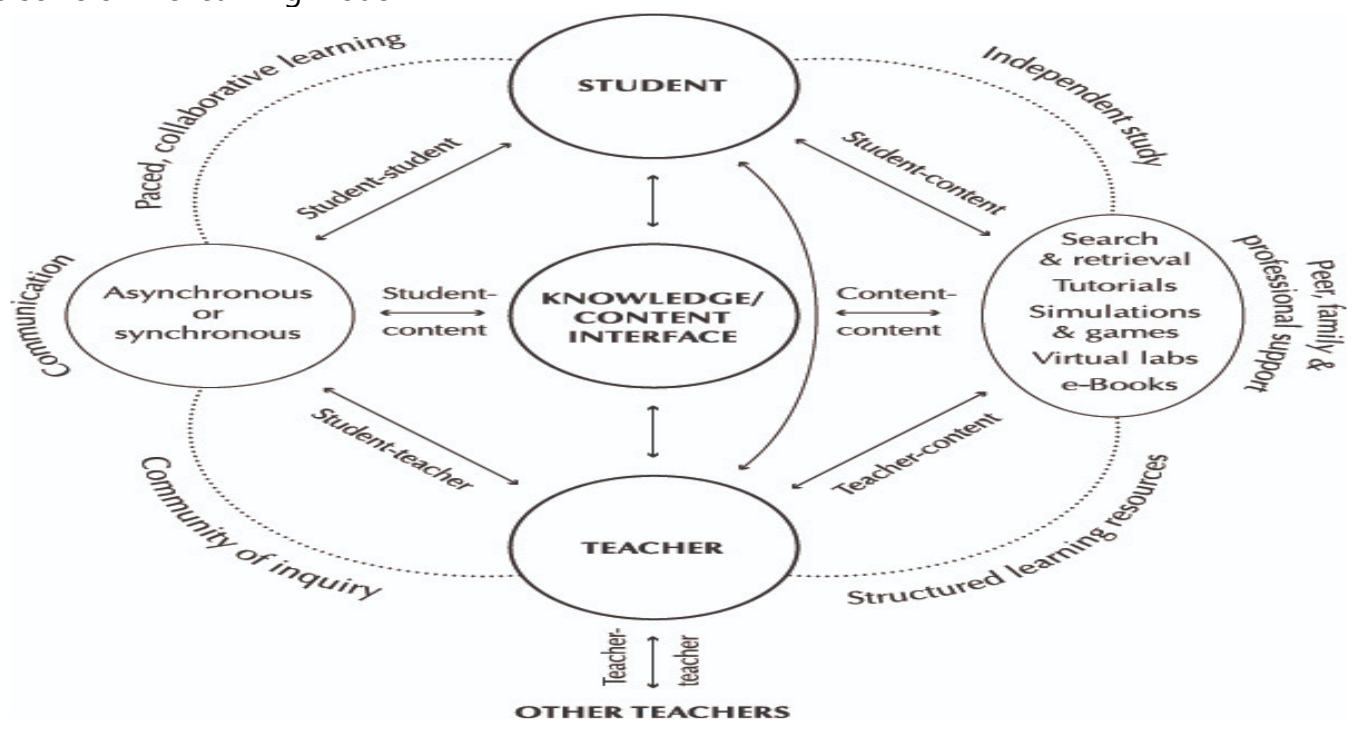




\subsection{Emergency Remote Teaching}

ERT is a temporary alternative to an online instructional mode due to crisis and differs from previous typical online courses (Hodges et al., 2020). For regular online teaching, besides delivering instructional content to students, teachers also address the significance of building a learning community for learners to engage and thus get social supports. The teaching materials, content, and activities used in ERT are primarily designed for physical learning environments but utilized in a virtual learning setting (Adedoyin \& Soykan, 2020; Bozkurt \& Sharma, 2020; Ferri et al., 2020; Mohmmed et al., 2020). Bozkurt et al. (2020) distinguished online learning and ERT by indicating that online learning is planned activities based on teachers' practical knowledge and grounded in educational theories, while ERT is for keeping education survival during a crisis by providing students with offline and online resources. Unlike in typical online classes where instructors are trained for teaching in the distance, in ERT classes, both students and their instructors had little or no experience with online education (Jeffery \& Bauer, 2020).

\subsection{Students' perceptions of online learning during COVID}

Educational researchers started working on students' perceptions of online learning since the outbreak of COVID-19. The majority of the literature shows a negative attitude towards the sudden transition to online learning. Students perceived the transition as a challenge mainly due to difficulties in concentrating on synchronous learning sessions, lack of peer communication or connections through networks, the loss of opportunities to support and encourage each other, and the instability of the internet (Bozkurt et al., 2020; Dhawan, 2020; Mohmmed et al., 2020; Shim \& Lee, 2020; Sun et al., 2020). For instance, Jeffery and Bauer (2020) investigated undergraduate students' responses to ERT in a chemistry online class. It was reported that as many as $80 \%$ of the students perceived the transition from F2F to online learning as a loss and a challenge because of the difficulties of concentration and interactions with peers. Thus, students found it challenging to engage and persist in virtual learning.

Similarly, in a study of grade 12 students' performance in Zambia (Sintema, 2020), students experienced difficulties interacting with teachers and peers remotely because of limited technology resources in the country. A negative attitude to online learning also appeared in China. In a survey study, university students in China indicated difficulties concentrating and self-management in online courses (Sun et al., 2020). Researchers in another study revealed that Ghanaian students had negative learning experiences because of low self-regulation and limited internet access (Owusu-Fordjour et al., 2020). Students in a university in South Korea expressed dissatisfaction with the instability of the internet and a lack of effective communication with their instructors and peers (Shim \& Lee, 2020). In a survey study conducted in the US, College students' motivation, self-efficacy, and cognitive engagement decrease after the transition to online learning (Moser et al., 2021). The result was mainly due to the lack of physical interaction with their instructors and other students.

Students' experience of ERT was not always negative. Studies reported students maintaining similar learning motivation to F2F learning, easy access to communication, and flexible learning time. For instance, a study analyzing South Korean college students' experiences also reflected positive features of ERT, including a flexible educational environment, active interactions, efficient time management (Shim \& Lee, 2020). A study with Philippian university students revealed that because of prior knowledge of technology, students and instructors adapted to online learning quickly, and students gained academic achievement at their convenient time because of the flexibility of asynchronous learning (Santos et al., 2021).

English learners' perspectives of online language learning during the time of COVID-19 can also be found in several studies. For instance, in a study by Huang et al. (2021), researchers investigated students' engagement in College English classes in China. They found that students held an extrinsic goal orientation while learning English, similar to their motivation in F2F learning. More importantly, ERT granted students more interactions with their instructor and peers than their previous F2F learning. Kholis (2020) found that WhatsApp for distance asynchronous English learning provided diverse types of instructional resources (e.g., PDF, Word, Excel, PowerPoint, video, voice, pictures) that students had easy access to. Another study (Kang, 2020) investigated international students in universities in Canada and found that they are exposed to challenges such as difficult access to social and academic support from universities, online test anxiety, and the lack of academic writing and speaking support tailored for them during the pandemic.

\section{Methodology}

This study adopted a photo-production visual method that participants use their devices to take photographs that act as tools for triggering memories (Frith, 2021; Mountian et al., 2021) of specific activities or scenes and revealing details of experiences (Pink, 2013). The participants took five to ten photographs or screenshots of the online learning process using their own devices and explored image-based experiences in the subsequent personal interviews (Busso, 2021; Frith, 2021; Guillemin \& Drew, 2010). Individual interviews were performed for a discussion of the pictures and related questions. Participants have blinded to the 
faces that appeared in the images. Compared with other qualitative methods, such as semi-structured interviews or focus groups, this method has the advantages of fostering a sense of participation and broadening access to data collection (Guillemin \& Drew, 2010; Roger \& Blomgren, 2019).

This study took place in a university in southern Ontario where a master's preparation program is dedicated to improving students' English language skills and help students gain confidence in academic situations. The recruitment of participants was based on a purposive convenience sampling method to reach the learners in the online classrooms at the research site. Four current ESL students, Emily, Daniel, Leon, Sam (all in pseudonyms; one female and three male students) participated in this study. At the time of this research project, two of the students were studying in China, one in India, and one in the province of British Columbia, Canada. They undertook this program to acquire English skills for academic development in the master's program. They were required to achieve an overall IELTS score of 6.5 .

\subsection{Data Analysis}

The interviews were transcribed into textual data, which were sent to the participants for member checking. The textual data, along with the images provided by the participants, were coded and categorized into themes. According to Anderson's (2011) online learning model, the themes were generated, such as inquiry between students and instructor and learning community, which are highly related to the purpose of the study and relevant to answer the research questions. One theme, instructors as mentors, was emergent from the interviews but still significant to understanding students' perceptions of online learning. The visual data were direct evidence of students' raw data and played an essential role in helping researchers understand what the participants valued about their learning experiences, including enjoyable activities, students' participation, and conversations in the community.

\section{Results}

Four themes were generated from data analysis, namely inquiry between students and instructor, instructor as a mentor, learning resources and approaches, and learning community. These themes were representatives of students' perceptions of online learning and encompassed expectations towards a more engaging learning experience in remote classes.

\subsection{Inquiry between students and instructor}

Students enjoyed multiple ways of inquiry, including texts, weblinks, images, and emojis, between students and their instructor. Emily indicated that group discussions were the primary interactive and collaborative approach among peers because they shared ideas and responded online. Figure 2 is a photograph Emily took during a discussion session. Her classmate shared a piece of science news, followed by oral responses to the instructors' questions. Other students read this article by clicking the link and participated in the discussion by adding comments on this article. Students were encouraged to find and share web sources related to the discussion topic, thus displaying an active role in-class engagement.

Figure 2: News link shared by a student
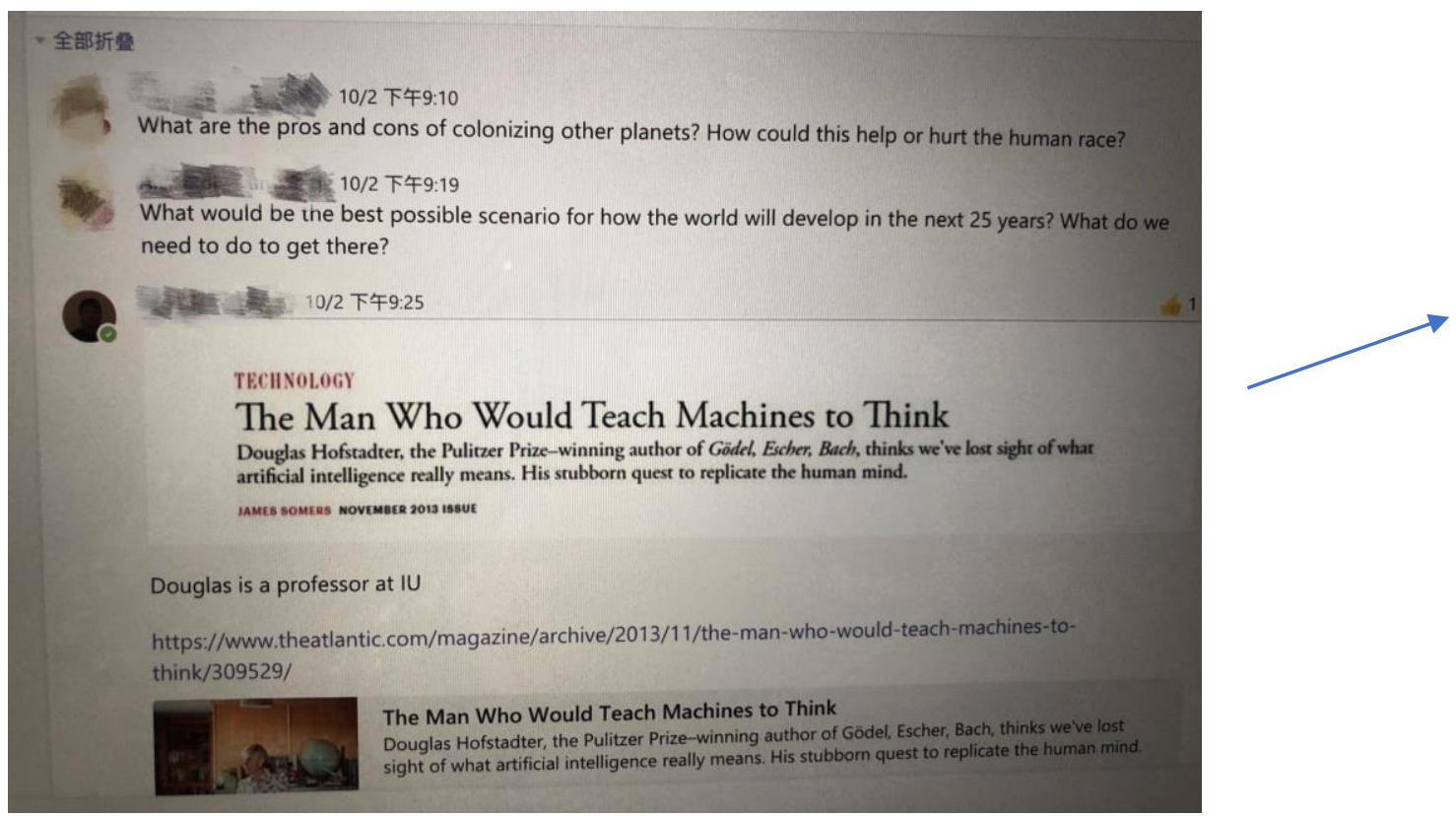
Daniel highlighted the unique feature of presenting images during online learning, including emojis and photographs. He perceived the usefulness, ease, and interests of using emojis to present feelings and respond to the instructor's questions. He also found photographs posted by other students provided a nonlinguistic narrative and helped understand their experiences. Figure 3 is students' responses using emojis and photographs when the instructor asked, "How was your reading week". Students used emojis to show their feelings and images to elicit their experiences, contributing to a further discussion of their vacation.

Figure 3: A screenshot of using emojis and sharing photographs

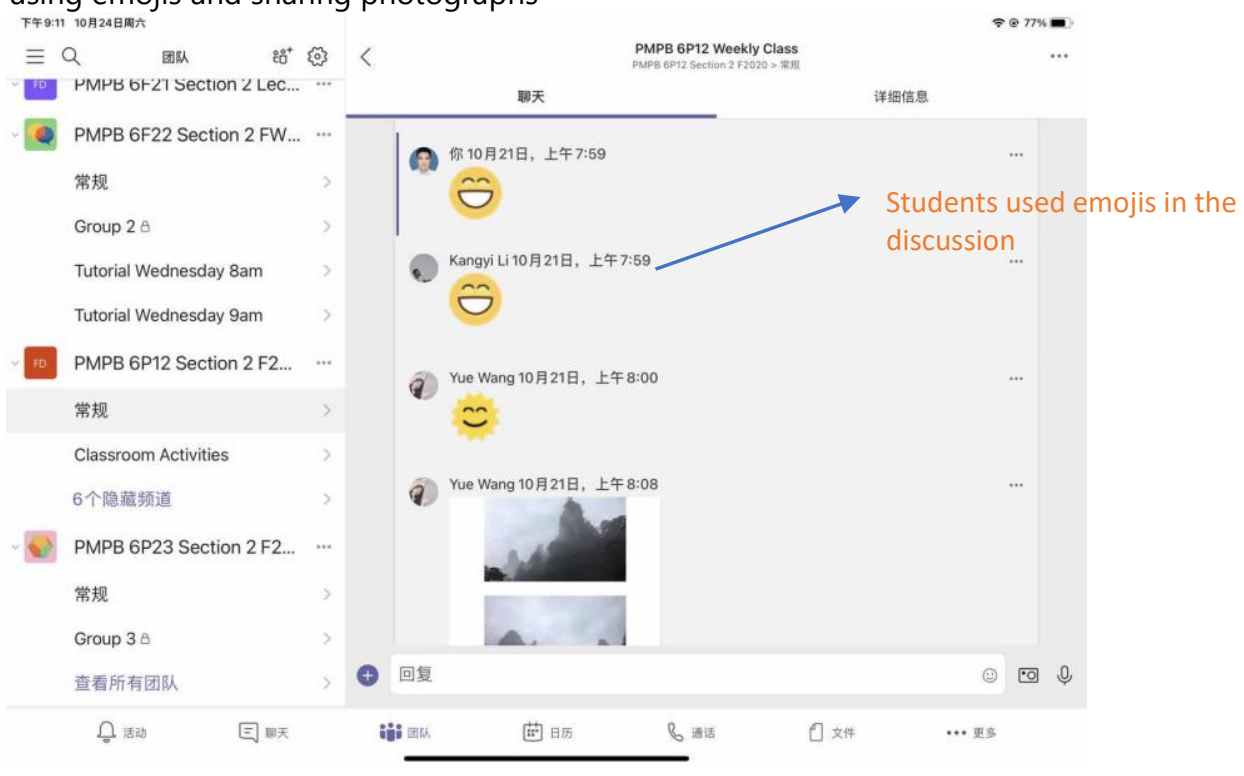

\subsection{Instructor as a mentor}

As described by two of the students, the instructor worked as a mentor to lead discussions by asking probes or more in-depth questions. The instructor's role in this section was to make sure students think critically and answer questions in logic. Emily was highly motivated to express thoughts because she assumed that "as long as you have your own opinions to support your statements, they are all acceptable". Thus, she perceived that the discussions promote critical thinking abilities. Thus, through actively engaging in the discussions under the instructor's scaffolding, Emily found this online course helpful for speaking abilities and beneficial for building a critical thinking stance.

As reflected by Leon and Sam, the instructor's feedback was mainly about the content students answered and rarely involved structural/grammatical accuracy. Many students attended this English program to improve their English skills and expected to finally meet the requirement of language tests for the master's program. However, the instructor could not meet their demand of perusing higher IELTS scores. Thus, Leon expected to receive more specific feedback and comments during the synchronous learning because he believed that instructors' feedback could enhance his speaking skills, thus elevating his IELTS scores.

Similar to Sam's experience, the instructor did not provide enough feedback as he expected. The feedback from the instructor usually was summaries or repetitions. He assumed more feedback if in F2F classes because physical connections may enhance knowledge acquisition.

Sam pointed out a drawback of online learning, lack of monitoring from the instructor. In this class, students were free to shut down their cameras and thus might do things unrelated to learning, which, however, could not be monitored by the instructor. Figure 4 is a screenshot of a lecture while some students having their cameras off. He supposed that in F2F classes, instructors could observe students' behaviors and thus make sure class engagement. He made a comment on the behavior of shutting down cameras as followed.

To be honest, because it is not required to open your camera, you have no idea what students are doing. Maybe they just opened the teams and went sleeping. You don't what they're doing. (Interview with Sam) 
Figure 4: A screenshot of learners in the meeting

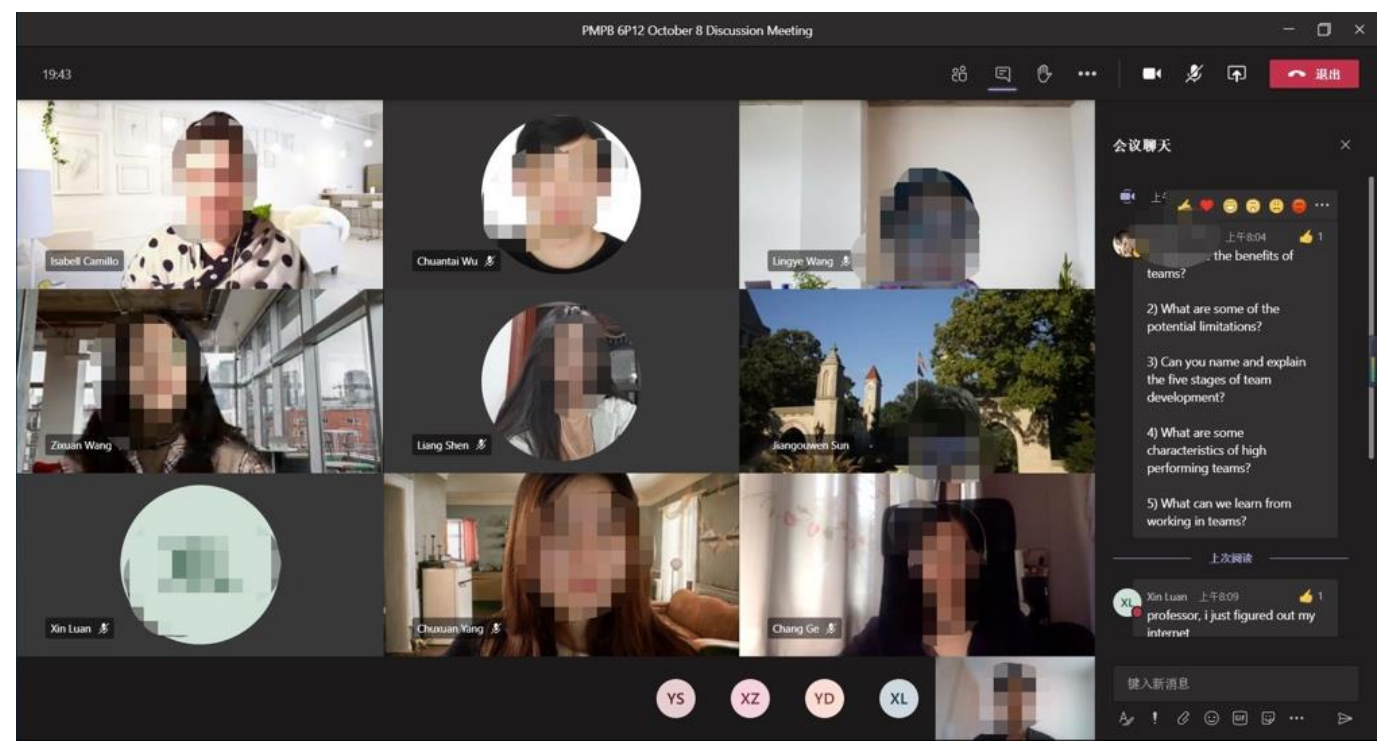

\subsection{Learning resources and approaches}

Daniel thought one advantage of online learning was the convenience of finding and storing online resources. He used his laptop to attend the lecture and used an iPad to take screenshots and store instructional materials and information shared by peers. He took notes and commented on those resources on the iPad, saving him time finding resources and printing the materials.

Game-based learning is an approach that Daniel enjoyed in this online learning course. The instructor introduced games that require students' input and output of language, during which they enjoyed the entertainment of playing games and practiced English listening and speaking skills. One game example is called Survival, in which each student played a role and discussed why they should survive while others could not. Students found this game interesting while maintaining practical challenges that could enhance their language improvement.

Leon perceived the one-by-one tutorial helpful to correct his pronunciations. Students read words of similar sounds provided by a teaching assistant during the tutorial, as shown in Figure 5. Leon thought he could not differentiate those words if without the tutorial. He was not sure the difference between $\mathrm{s}$ and th. The teaching assistant helped with figuring that out. However, he also found that it was difficult to change his incorrect pronunciations. Besides pronunciation tutorials, he expected more specific feedback on his speaking skills to prepare him for the IELTS test.

Figure 5: One-by-one pronunciation tutorial

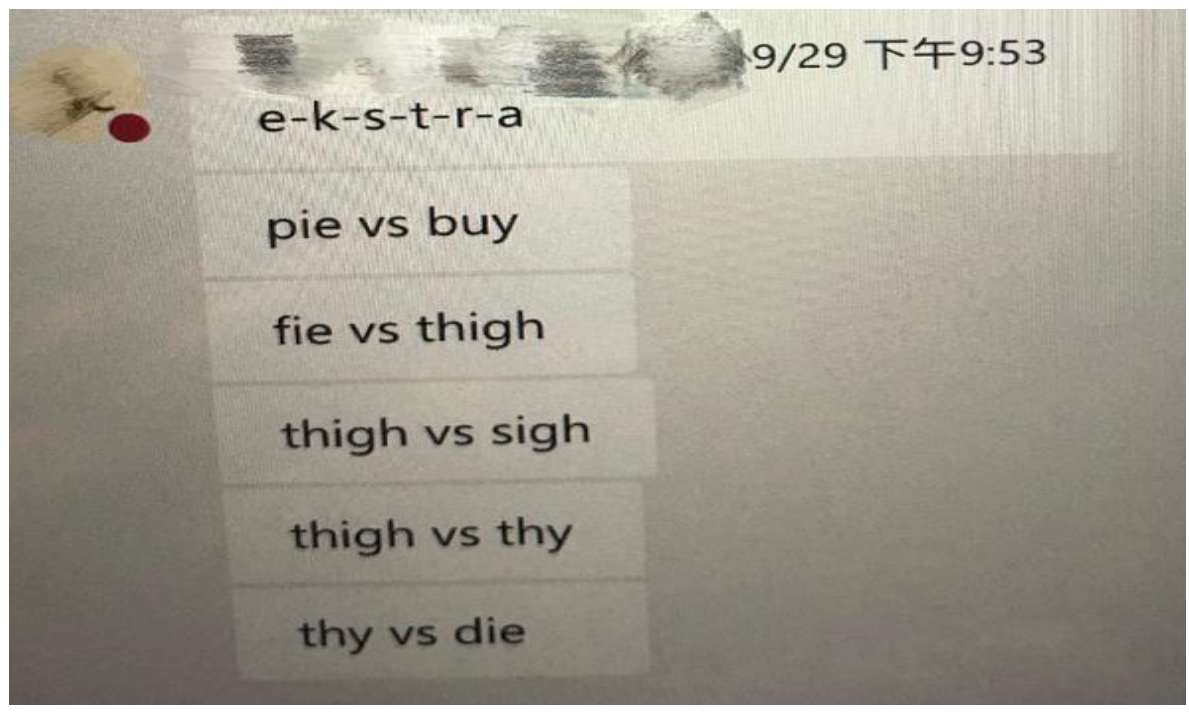




\subsection{Learning community}

Emily introduced a drawback of this online learning that the classmates were "strangers" because the overlapping of their lives was only through the short online period so that they had limited knowledge about each other. She told a story about a classmate to showcase the lack of a sense of community.

In this online class, even though you think that you know a person very well, your relationship is all based online. We had a classmate who came to the class for only about two weeks and then he disappeared. Our professor in the class asked us why this classmate did not show up, but nobody knew it because we did not know each other well.

From Leon's perspective, this online learning model did not differ significantly from F2F classes except that they could not see people physically. Most of the learning procedures that happen in F2F learning had been realized in this virtual learning model. Yet, since he was still taking online courses in China, his home country, he lacked an English language environment after class.

Sam said that many Chinese students were shy to answer or ask questions in public, and they preferred to have individual conversations after class. If in physical classrooms, students could have instant conversations or discussions after lectures. However, in this online learning environment, they had to schedule a meeting for discussions, which are not as convenient as F2F discussions. Instead of asking questions in person, students had to make appointments to reach their instructor. As a result, because students lacked instant communication opportunities, they might postpone their questions or forget to figure them out.

\section{Discussion}

\subsection{What are students' perceptions of online learning compared to F2F classes?}

The four participants perceived limited differences between F2F and online English-speaking learning. The learning content involving speaking activities for individuals' answers, group discussions and presentations for collaborations, feedback from the instructor, and tutorial sections to correct pronunciation, similar to typical F2F content. Those structured resources and learning approaches are similar to findings in other studies (Kholis, 2020; Shim \& Lee, 2020). Those features of online learning are beyond the purpose of emergency remote teaching: survival of education. Online learning in this university has been developed beyond simply delivering offline or online resources to students. This online teaching enabled multiple computer-mediated interactions to serve students' understanding of discussion questions and their information exchanges and meets the affordances of computer-assisted language learning (Anderson, 2011; Beatty, 2013; Lenkaitis, 2020; Warschauer, 2004; Xue \& Churchill, 2020).

Those participants agreed on the distinguishing feature of information exchanging in this virtual environment. They found the efficiency of learning online because of the ease of information sharing and receiving, consistent with existing research (AlEmran \& Teo, 2020; Chang, 2018; Smith, 2014). Besides presenting ideas orally, students also made use of text-based and visual methods for communication. Multiple types of input and output of language contributed to their understanding of questions and enriched their information (Caws \& Hamel, 2016; Gatbonton, 2000; Krashen, 1985; McCarty et al., 2017). This online class also enabled many-to-many communication in the synchronous group discussions (Brown et al., 2016; Kop, 2011), where any of the students could initiate by presenting ideas and jump in for inputting thoughts. Place-independent communication is also well exemplified in this study since students in this class are mostly studying in their home countries worldwide, allowing longdistance communications among the community members (Eom et al., 2006; Northey et al., 2018; Wang et al., 2009; Warschauer, 2004).

Students were satisfied with the design of this course, which involves discussing questions that became challenging gradually. The conversations with their instructor and peers enriched their ways of thinking and cultivated their critical thinking abilities. Long-distance collaboration enables students from various backgrounds to work together to develop solutions to problems, deal with real-life issues, and contribute to their critical thinking abilities (Asoodar et al., 2014; Jaipal-Jamani \& Figg, 2015; Warschauer, 2004). Canadian education takes critical thinking as a goal to achieve through, including "think[ing] clearly, rationally, and independently" (Gereluk et al., 2016, p. 76). The exploration of knowledge is a process of not simply accepting or memorizing but also covering questioning, debating, connecting, judging, evaluating, and creating. Students' experiences are evidence that instructors' curriculum designs are following this educational goal.

From students' narratives, instructors were well-prepared for using the online platforms, including Sakai, Microsoft Teams, and Connects, and could switch between platforms for multiple instructional tasks. This phenomenon shows a better readiness for technology-supported teaching and learning compared to studies in other countries. For instance, in the Philippines, the instructors used personal social media instead of educational platforms to deliver instructional content for distance learning (Bozkurt et al., 2020). In China, the instructors used platforms specifically for learning, such as Rain Classroom. However, this platform was designed for mobile-assisted physical classrooms (Huang et al., 2021). Those comparisons are evidence of good preparation of formal learning technologies in this university. 
One concern of online learning raised by students was low self-regulation in the online learning process. It is challenging for students to regulate themselves on learning in the virtual learning environment. Self-regulation is regarded as a critical competence in distance learning(de Araujo Guerra Grangeia et al., 2016; Henrie et al., 2015; Kuo et al., 2014). Without instructors' significant control over the learning process as in F2F classes, students need to rely on their self-regulation to achieve effective and efficient learning (Artino \& McCoach, 2008). Also, students were easily distracted from learning because of the lack of monitoring from the instructor physically. This result is similar to previous research comparing students' self-regulation in online classes and F2F classes. For instance, Bao (2020) found that students' self-regulation is lower than in F2F classes because instructors had less control over online teaching. Huang et al. (2021) demonstrated that students' self-regulation and effort regulation in emergency online classes are significantly lower than students' perception of the course's task value.

\subsection{What are the designs or activities that provide speaking opportunities and enhance speaking skills?}

This online course follows a typical design of student-centered online learning in a constructivist stance (Anderson, 2011; Cohen \& Holstein, 2018; Minocha et al., 2011; Picciano, 2017), involving types of speaking activities, such as synchronous communication, group discussion, and group presentation. Students were given questions or topics for individual answers or collaborative responses from groups. Their discussion questions involved resources from textbooks or the instructor's input. Students also shared personal photographs, individual stories, web resources, et cetera to elicit discussions about life experiences, such as extracurricular activities and cultural elements to enrich learning resources (Knowlton, 2000) that go beyond structured materials that were suggested by Anderson (2011).

To create and disseminate knowledge, students participated in online activities that engaged multiple communication types, including web resources, traditional resources, students' life experience, and problem-solving activities and evaluations. Students' involvement in this course is consistent with Knowlton's (2000) framework of constructing a student-centered online classroom by encouraging them to "contribute resources of them own and share from their own personal practical knowledge that has developed as a result of their unique experience" (p. 12). Students occupy a central role in this classroom model; collaboration and communication can promote effective learning. The instructors' role in this type of learning is no longer an umpire, judge, and dictator but a coach, counselor, and mentor to help with students' construction of knowledge, consistent with a constructivist approach of active learning (Anderson, 2011; Warschauer, 2004).

The feedback from the instructor was mainly towards meaning communication instead of the accuracy of grammatical roles, aligning with task-based language teaching that focuses on meaning instead of forms. By participating in tasks, students pay more attention to meaningful input and production of the target language (Baralt \& Gomez, 2017; Ellis, 2003; Nassaji \& Fotos, 2011). Students finished speaking tasks, which can be a brief practice exercise, such as a group discussion of a topic, with a spontaneous communication of meaning (Breen, 1987). Students used English for communicative purposes in those learning activities to reach a learning outcome, such as negotiation strategies with customers and advertising new products on markets, fitting Willis and Willis's (2013) description of tasks. Also, students engage in those learning activities by expressing their thoughts, putting forward solutions to questions, and generating arguments in group discussion. This type of activity is also in line with Herrington et al.'s (2003) definition of tasks as they put forward that tasks are activities in which learners engage to achieve an objective learning goal. Students were positive with this type of teaching approach as it puts students into the center of learning and they felt engaged through the process of finishing the tasks. As He (2013) suggests, students construct speaking confidence through practices that do not overconcern correctness because their grammatical mistakes were not judged.

Students perceived difficulties in having instant conversations with their instructor when they had questions in the virtual class because they had to book an appointment rather than talking to their instructor in person after class. Students' unwillingness to communicate in public may attribute to foreign language anxiety in an unfamiliar setting (Jackson, 2008). The overemphasis on correctness in English teaching traditions is deeply rooted in students' cognitions (He, 2013), making it difficult to express thoughts in public to avoid being laughed at. Thus, instructors need to construct a caring and welcoming environment, thus building students' confidence in speaking in a foreign language. As Liu and Jackson (2008) suggest, facilitating interactive group activities and calling on students in a nonthreatening manner are approaches to instructors to reduce students' anxiety and build up their confidence in speaking.

\subsection{What are the students' expectations of activities to inform the designing of online teaching?}

Students expect to participate in more types of interactive and collaborative activities that can help them know their peers and thus construct a sense of belonging to this community. The engagement in collaborative activities contributes to students' sense of community and is a primary way of constructing knowledge in online learning, as researchers suggested (Beldarrain, 2006; Jeong \& Hmelo-Silver, 2016; Knowlton, 2000; Kukulska-Hulme \& Viberg, 2018). This learning approach, however, was engaged in limited sections or phases in this online course. This result is parallel with previous research that students' persistence of 
engagement in online learning was highly correlated to the community constructed with their instructor and peers, which, however, was difficult to achieve in the virtual environment (Baralt $\&$ Gomez, 2017; Santos et al., 2021). The sense of community has been demonstrated as a factor influencing students' effectiveness of online learning amidst COVID (Mustafa et al., 2021; Santos et al., 2021). Students in online classrooms mostly rely on their contribution and participation in the learning procedure to showcase their existence in the virtual environment. In order to eliminate the differences between online and F2F learning, activities that involve visual, audible, behavioral clues, and senses should be incorporated to help construct more social connections (Henrie et al., 2015; Knowlton, 2000). Students participate in collaborative learning projects to present ideas, get feedback, and become socially and intellectually engaged.

Because of the particular time of COVID and travel restrictions, those ESL students who are currently living outside of Canada felt a strong desire to obtain English training for everyday use. In traditional F2F situations, students had the chance to have conversations with peers before or after class and practice spoken English for daily use. However, those online learners are currently living in their home countries where English is a foreign language, and students have rare opportunities for practicing speaking skills (Li, 2016). In this online class, though students had opportunities for interaction and collaboration with peers in activities. Those activities, however, are designed only for academic English-speaking skills. Thus, it became a request for more support on informal English usage from students who desire to achieve integrative purposes.

Teachers can choose from various online lecture software and digital teaching approaches to enrich activity options; students can be allowed to act as creators of learning activities and resources, developing an interactive and participatory learning environment (C. Liu et al., 2017). Students also indicated the preference for more game-like activities to bring more entertainment to their learning. Game-based learning enables enjoyment of finishing games and a sense of achievement in winning and helping peers (L.-H. Wong \& Hsu, 2016). A combination of games and technology, such as implementing games during online learning, motivates learners and fits the preferences of digital natives born in the digital age (Berns et al., 2016), thus enhancing learner engagement and language proficiency.

Students received feedback on content, which was not enough to improve their examination-oriented language skills. Students are concerned about their IETLS tests and sought support from their online classes. They expected more corrective feedback on forms to enhancing accuracy for achieving the instrumental motivation of taking language tests. Corrective feedback can draw students' attention to forms, facilitating their notice of the gap between their incorrect oral expression and target forms (Kartchava et al., 2020). Wong and Waring (2020) suggested that corrective feedback from instructors and peers helps learners be aware of language complexity and become interactionally competent. Thus, it is expected that students receive more corrective feedback to obtain language achievements towards academic goals.

\section{Conclusion}

This study investigated ESL students' learning experience in a remote speaking class during the pandemic of COIVD-19. Students perceived online ESL learning as similar to their previous F2F learning experience, with interactive and collaborative learning activities for practicing spoken English. The designing of the learning process aligns with typical online learning designs, such as Anderson's (2011) online learning model and Knowlton's (2000) framework of constructing a student-centered online classroom, enabling students' active participation and demonstrating a satisfying transfer to online learning. This online speaking class exemplified multiple types of inquiry, such as texts, images, emojis, weblinks, and group discussions, between students and instructors in the virtual space, enabling many-to-many multimodal communication. Students perceived the instructor as a mentor who encouraged them to think critically while obtaining speaking skills, contributing to students' academic achievements under the requirement of higher education in Canada. The language teaching pedagogy fits the features of task-based language teaching, such as focusing on meaning instead of forms. Students perceived this type of teaching as beneficial for building the confidence of speaking a foreign language but not adequate for the preparation of IELTS tests. Thus, they expected to involve more types of learning activities that can foster a sense of community among learners and to obtain more corrective feedback of speaking skills. This study also provides suggestions on adjusting instructors' online teaching process according to students' needs and expectations.

\section{Implication}

The shift to remote learning has been a challenge for ESL students who potentially sought the acquisition of language skills in an English language communication environment. Remote teaching from a global distance during the pandemic has reshaped those students' learning experience worth researchers' attention. The investigation of ESL students' live experience in an online speaking course showcases English learning in a virtual environment with a focus on students' needs for academic achievement and language acquisition. Students' perceptions of online language learning, particularly of speaking skills that should be achieved through real-person communications, will inform the designing of learning activities that match the agenda of student- 
centered online learning. This investigation will also contribute to the return to regular F2F education by enhancing the adoption of beneficial features and affordances of technology-based learning into F2F classrooms. A hybrid learning model that employs students' digital devices in normal classrooms has the potential of constructing a more welcoming and interactive learning community than either of the single approaches. The findings in this study may also benefit teacher training, with an emphasis on enhancing higher education instructors' technology-based instructional skills, thus elevating students' overall experience of online learning and hybrid learning during the pandemic and in the post-pandemic era.

\section{References}

[1] Adedoyin, O. B., \& Soykan, E. (2020). Covid-19 pandemic and online learning: The challenges and opportunities. Interactive Learning Environments, 1-13. https://doi.org/10.1080/10494820.2020.1813180

[2] Ahn, T. Youn, \& Lee, S.-M. (2016). User experience of a mobile speaking application with automatic speech recognition for EFL learning. British Journal of Educational Technology, 47(4), 778-786. https://doi.org/10.1111/bjet.12354

[3] Alderete-Diez, P., McLoughlin, L., \& Dhonnchadha, L. (2012). Translation, technology and autonomy in language teaching and learning. Oxford; New York: Peter Lang. https://www.peterlang.com/view/title/35451

[4] Al-Emran, M., \& Teo, T. (2020). Do knowledge acquisition and knowledge sharing really affect e-learning adoption? An empirical study. Education and Information Technologies, 25(3), 1983-1998. https://doi.org/10.1007/s10639-019-10062-w

[5] Anderson, T. (2011). Towards a theory of online learning. In The theory and practice of online learning. AU Press-Digital Publications. https://read.aupress.ca/read/the-theory-and-practice-of-online-learning/section/4d56145b-d99a-474d-9bcb-de69f3683622\#ch02

[6] Artino, A. R., \& McCoach, D. B. (2008). Development and initial validation of the online learning value and self-efficacy scale. Journal of Educational Computing Research, 38(3), 279-303. https://doi.org/10.2190/EC.38.3.c

[7] Asoodar, M., Atai, M. R., Vaezi, S., \& Marandi, S. S. (2014). Examining effectiveness of communities of practice in online English for academic purposes (EAP) assessment in virtual classes. Computers \& Education, 70, 291-300. https://doi.org/10.1016/j.compedu.2013.08.016

[8] Bao, W. (2020). COVID-19 and online teaching in higher education: A case study of Peking University. Human Behavior and Emerging Technologies, 2(2), 113-115. https://doi.org/10.1002/hbe2.191

[9] Baralt, M., \& Gomez, J. M. (2017). Task-based language teaching online: A guide for teachers. Language Learning \& Technology, 21(3), 2843.

[10] Barron, D., \& Zeegers, M. (2006). Subjects of Western education: Discursive practices in Western postgraduate studies and the construction of international student subjectivities. The Australian Educational Researcher, 33(2), 77-96. https://doi.org/10.1007/BF03216835

[11] Beatty, K. (2013). Teaching \& researching: Computer-assisted language learning. Routledge.

[12] Beldarrain, Y. (2006). Distance education trends: Integrating new technologies to foster student interaction and collaboration. Distance Education, 27(2), 139-153. https://doi.org/10.1080/01587910600789498

[13] Berns, A., Isla-Montes, J.-L., Palomo-Duarte, M., \& Dodero, J.-M. (2016). Motivation, students' needs and learning outcomes: A hybrid game-based app for enhanced language learning. SpringerPlus, 5(1), 1305. https://doi.org/10.1186/s40064-016-2971-1

[14] Bozkurt, A., Jung, I., Xiao, J., Vladimirschi, V., Schuwer, Egorov, Gennady, Lambert, Sarah R, Al-Freih, Maha, Pete, Judith, Olcott, Jr. Don, Rodes, Virginia, Aranciaga, Ignacio, Bali, Maha, Alvarez, A. V., Roberts, Jennifer, Pazurek, Angelica, Raffaghelli, Juliana Elisa, Panagiotou, Nikos, Coëtlogon, Perrine de, ... Paskevicius, Michael. (2020). A global outlook to the interruption of education due to COVID-19 pandemic: Navigating in a time of uncertainty and crisis. https://doi.org/10.5281/ZENODO.3878572

[15] Bozkurt, A., \& Sharma, R. C. (2020). Emergency remote teaching in a time of global crisis due to Coronavirus pandemic. Asian Journal of Distance Education, 15(1), 1-6.

[16] Breen, M. P. (1987). Contemporary Paradigms in Syllabus Design. Part I. Language Teaching, 20(2), 81-92. https://doi.org/10.1017/S0261444800004365

[17] Brown, B., Schroeder, M., \& Eaton, S. E. (2016). Designing synchronous online interactions and discussions. In M. Takeuchi, A. Preciado Babb, \& J. Lock, Proceedings of the IDEAS: Designing for Innovation (pp. 51-60). University of Calgary.

[18] Busso, L. D. (2021). Using photographs to explore the embodiment of pleasure in everyday life. In P. Reavey, Visual methods in psychology: Using and interpreting images in qualitative research (pp. 70-82). Routledge.

[19] Caws, C., \& Hamel, M.-J. (2016). Language-Learner Computer Interactions: Theory, methodology and CALL applications. John Benjamins Publishing Company. https://library.oapen.org/handle/20.500.12657/25981

[20] Chang, B. (2018). Active Knowledge Sharing in Online Group Work. New Horizons in Adult Education and Human Resource Development, 30(3), 41-59. https://doi.org/10.1002/nha3.20222

[21] Clouder, L., Dalley, J., Hargreaves, J., Parkes, S., Sellars, J., \& Toms, J. (2006). Electronic [re]constitution of groups: Group dynamics from face-to-face to an online setting. International Journal of Computer-Supported Collaborative Learning, 1(4), 467-480. https://doi.org/10.1007/s11412-006-9002-0

[22] Cohen, A., \& Holstein, S. (2018). Analysing successful massive open online courses using the community of inquiry model as perceived by students. Journal of Computer Assisted Learning, 34(5), 544-556. https://doi.org/10.1111/jcal.12259

[23] de Araujo Guerra Grangeia, T., de Jorge, B., Franci, D., Martins Santos, T., Vellutini Setubal, M. S., Schweller, M., \& de Carvalho-Filho, M. A. (2016). Cognitive load and self-determination theories applied to e-learning: Impact on students' participation and academic performance. PLOS ONE, 11(3), 1-21. https://doi.org/10.1371/journal.pone.0152462

[24] Dhawan, S. (2020). Online Learning: A Panacea in the Time of COVID-19 Crisis. Journal of Educational Technology Systems, 49(1), 5-22. https://doi.org/10.1177/0047239520934018

[25] Ellis, R. (2003). Task-based language learning and teaching. Oxford University Press. 
[26] Eom, S. B., Wen, H. J., \& Ashill, N. (2006). The determinants of students' perceived learning outcomes and satisfaction in university online education: An empirical investigation*. Decision Sciences Journal of Innovative Education, 4(2), 215-235. https://doi.org/10.1111/j.15404609.2006.00114.x

[27] Esteves, M., Fonseca, B., Morgado, L., \& Martins, P. (2011). Improving teaching and learning of computer programming through the use of the Second Life virtual world. British Journal of Educational Technology, 42(4), 624-637. https://doi.org/10.1111/j.1467-8535.2010.01056.x

[28] Falloon, G. (2011). Making the connection: Moore's theory of transactional distance and its relevance to the use of a virtual classroom in postgraduate online teacher education. Journal of Research on Technology in Education, 43(3), 187-209. https://doi.org/10.1080/15391523.2011.10782569

[29] Fay, D. L., \& Ghadimi, A. (2020). Collective bargaining during times of crisis: Recommendations from the COVID-19 pandemic. Public Administration Review, 80(5), 815-819. https://doi.org/10.1111/puar.13233

[30] Ferri, F., Grifoni, P., \& Guzzo, T. (2020). Online learning and emergency remote teaching: Opportunities and challenges in emergency situations. Societies, 10(4), 1-18. https://doi.org/10.3390/soc10040086

[31] Frith, H. (2021). Narrating biographical disruption and repair. In P. Reavey, Visual methods in psychology: Using and interpreting images in qualitative research (pp. 83-96). Routledge.

[32] Gatbonton, E. (2000). Investigating experienced ESL teachers' pedagogical knowledge. Canadian Modern Language Review, 4, 585.

[33] Gereluk, D., Maxwell, B., Norris, T., \& Martin, C. (2016). Questioning the classroom: Perspectives on Canadian education. Oxford University Press.

[34] Ghaith, G., \& Shaaban, K. (2005). Cooperative learning for the disaffected ESL/EFL learner. International Journal on School Disaffection, 3, 44-47. https://doi.org/10.18546/IJSD.03.2.09

[35] Guillemin, M., \& Drew, S. (2010). Questions of process in participant-generated visual methodologies. Visual Studies, 25(2), $175-188$. https://doi.org/10.1080/1472586X.2010.502676

[36] Haley, M. H., \& Austin, T. Y. (2004). Content-based second language teaching and learning: An interactive approach. Pearson/Allyn and Bacon. https://catalog.hathitrust.org/Record/004345597

[37] He, D. (2013). What makes learners anxious while speaking English: A comparative study of the perceptions held by university students and teachers in China. Educational Studies, 39(3), 338-350. https://doi.org/10.1080/03055698.2013.764819

[38] Henrie, C. R., Halverson, L. R., \& Graham, C. R. (2015). Measuring student engagement in technology-mediated learning: A review. Computers \& Education, 90, 36-53. https://doi.org/10.1016/j.compedu.2015.09.005

[39] Herrington, J., Oliver, R., \& Reeves, T. C. (2003). Patterns of engagement in authentic online learning environments. Australasian Journal of Educational Technology, 19(1), Article 1. https://doi.org/10.14742/ajet.1701

[40] Hodges, C., Moore, S., Lockee, B., Trust, T., \& Bond, A. (2020). The difference between emergency remote teaching and online learning. EDUCAUSE Review. https://er.educause.edu/articles/2020/3/the-difference-between-emergency-remote-teaching-and-online-learning

[41] Huang, M., Shi, Y., \& Yang, X. (2021). Emergency remote teaching of English as a foreign language during COVID-19: Perspectives from a university in China. IJERI: International Journal of Educational Research and Innovation, 15, 400-418. https://doi.org/10.46661/ijeri.5351

[42] Jaipal-Jamani, K., \& Figg, C. (2015). A Case Study of a TPACK-Based Approach to Teacher Professional Development: Teaching Science With Blogs. 40.

[43] Jeffery, K. A., \& Bauer, C. F. (2020). Students' responses to emergency remote online teaching reveal critical factors for all teaching. Journal of Chemical Education, 97(9), 2472-2485. https://doi.org/10.1021/acs.jchemed.0c00736

[44] Jeong, H., \& Hmelo-Silver, C. E. (2016). Seven affordances of computer-supported collaborative learning: How to support collaborative learning? How can technologies help? Educational Psychologist, 51(2), 247-265. https://doi.org/10.1080/00461520.2016.1158654

[45] Kang, P. (2020). Towards sustainable internationalization in post-COVID higher education in Canada. Migration and Language Education, 1(2), 60-73. https://doi.org/doi.org/10.29140/mle.v1n2.383

[46] Kartchava, E., Gatbonton, E., Ammar, A., \& Trofimovich, P. (2020). Oral corrective feedback: Pre-service English as a second language teachers' beliefs and practices. Language Teaching Research, 24(2), 220-249. https://doi.org/10.1177/1362168818787546

[47] Kassem, M. A. M. (2018). Improving EFL students' speaking proficiency and motivation: A hybrid problem-based learning approach. Theory and Practice in Language Studies, 8(7), 848-860. https://doi.org/10.17507/tpls.0807.17

[48] Kholis, A. (2020). The use of whatsapp app in distance language learning in pandemic Covid-19: A case study in Nahdlatul Ulama university of Yogyakarta. LET: Linguistics, Literature and English Teaching Journal, 10(2), 24-43. https://doi.org/10.18592/let.v10i2.4051

[49] Knowlton, D. S. (2000). A theoretical framework for the online classroom: A defense and delineation of a student-centered pedagogy. New Directions for Teaching and Learning, 2000(84), 5-14. https://doi.org/10.1002/tl.841

[50] Kop, R. (2011). The challenges to connectivist learning on open online networks: Learning experiences during a massive open online course. The International Review of Research in Open and Distributed Learning, 12(3), 19-38. https://doi.org/10.19173/irrodl.v12i3.882

[51] Krashen, S. D. (1985). Second language acquisition and second language learning (Reprinted). Pergamon Pr.

[52] Kukulska-Hulme, A., \& Viberg, O. (2018). Mobile collaborative language learning: State of the art: Mobile collaborative language learning. British Journal of Educational Technology, 49(2), 207-218. https://doi.org/10.1111/bjet.12580

[53] Kuo, Y.-C., Walker, A. E., Schroder, K. E. E., \& Belland, B. R. (2014). Interaction, internet self-efficacy, and self-regulated learning as predictors of student satisfaction in online education courses. The Internet and Higher Education, 20, 35-50. https://doi.org/10.1016/j.iheduc.2013.10.001

[54] Lenkaitis, C. A. (2020). Technology as a mediating tool: Videoconferencing, L2 learning, and learner autonomy. Computer Assisted Language Learning, 33(5-6), 483-509. https://doi.org/10.1080/09588221.2019.1572018

[55] Li, Q. (2016). Changes in the motivation of Chinese ESL learners: A qualitative investigation. English Language Teaching, 10(1), 112-122. https://doi.org/10.5539/elt.v10n1p112

[56] Liu, C., Chen, W.-C., Lin, H.-M., \& Huang, Y.-Y. (2017). A remix-oriented approach to promoting student engagement in a long-term participatory learning program. Computers \& Education, 110, 1-15. https://doi.org/10.1016/j.compedu.2017.03.002 
[57] Liu, M., \& Jackson, J. (2008). An exploration of Chinese EFL learners' unwillingness to communicate and foreign language anxiety. The Modern Language Journal, 92(1), 71-86. https://doi.org/10.1111/j.1540-4781.2008.00687.x

[58] Lotfi, A. R., \& Pozveh, S. M. H. H. (2019). The effect of synchronous and asynchronous language learning: A study of Iranian EFL intermediate students' vocabulary learning. Theory and Practice in Language Studies, 9(12), 1585-1595. https://doi.org/10.17507/tpls.0912.16

[59] McCarty, S., Obari, H., \& Sato, T. (2017). Implementing mobile language learning technologies in Japan. Springer Singapore. https://doi.org/10.1007/978-981-10-2451-1

[60] Minocha, S., Schroeder, A., \& Schneider, C. (2011). Role of the educator in social software initiatives in further and higher education: A conceptualisation and research agenda. British Journal of Educational Technology, 42(6), 889-903. https://doi.org/10.1111/j.14678535.2010.01131.x

[61] Mohmmed, A. O., Khidhir, B. A., Nazeer, A., \& Vijayan, V. J. (2020). Emergency remote teaching during Coronavirus pandemic: The current trend and future directive at Middle East College Oman. Innovative Infrastructure Solutions, 5(3), 1-11. https://doi.org/10.1007/s41062-02000326-7

[62] Moore, R. L. (2016). Interacting at a distance: Creating engagement in online learning environments. In L. Kyei-Blankson, J. Blankson, E. Ntuli, \& C. Agyeman (Eds.), Handbook of Research on Strategic Management of Interaction, Presence, and Participation in Online Courses: IGI Global. https://doi.org/10.4018/978-1-4666-9582-5

[63] Moradi, M., Liu, L., Luchies, C., Patterson, M. M., \& Darban, B. (2018). Enhancing teaching-learning effectiveness by creating online interactive instructional modules for fundamental concepts of physics and mathematics. Education Sciences, 8(3), 109. https://doi.org/10.3390/educsci8030109

[64] Moser, K. M., Wei, T., \& Brenner, D. (2021). Remote teaching during COVID-19: Implications from a national survey of language educators. System, 97, 102431. https://doi.org/10.1016/j.system.2020.102431

[65] Mountian, I., Lawthom, R., Kellock, A., Duggan, K., Sixsmith, J., Kagan, C., Hawkins, J., Haworth, J., Siddiquee, A., Worley, C., Brown, D., Griffiths, J., \& Purcell, C. (2021). On utilizing a visual methodology: Shared reflections and tensions. In P. Reavey, Visual methods in psychology: Using and interpreting images in qualitative research (pp. 572-587). Routledge.

[66] Mustafa, D. F., Khursheed, A., Rizvi, S. M. U., Zahid, A., \& Akhtar, A. (2021). Factors influencing online learning of university students under the covid-19 pandemic. IJERI: International Journal of Educational Research and Innovation, 15, 342-359. https://doi.org/10.46661/ijeri.5432

[67] Nassaji, H., \& Fotos, S. S. (2011). Teaching grammar in second language classrooms: Integrating form-focused instruction in communicative context. Routledge.

[68] Nguyen, T.-H., Hwang, W.-Y., Pham, X.-L., \& Ma, Z.-H. (2018). User-oriented EFL speaking through application and exercise: Instant speech translation and shadowing in authentic context. Journal of Educational Technology \& Society, 21(4), 129-142.

[69] Northey, G., Govind, R., Bucic, T., Chylinski, M., Dolan, R., \& Esch, P. van. (2018). The effect of "here and now" learning on student engagement and academic achievement. British Journal of Educational Technology, 49(2), 321-333. https://doi.org/10.1111/bjet.12589

[70] Owusu-Fordjour, C., Koomson, C. K., \& Hanson, D. (2020). The impact of COVID-19 on learning-The perspective of the ghanaian student. European Journal of Education Studies, 7(3), 88-101. https://doi.org/10.5281/ZENODO.3753586

[71] Pace, C., Pettit, S., \& Barker, K. (2020). Best practices in middle level quaranteaching: Strategies, tips and resources amidst COVID-19. Becoming: Journal of the Georgia Middle School Association, 31(1), 1-13. https://doi.org/10.20429/becoming.2020.310102

[72] Picciano, A. G. (2017). Theories and frameworks for online education: Seeking an integrated model. Online Learning, 21(3). https://doi.org/10.24059/olj.v21i3.1225

[73] Pink, S. (2013). Doing Visual Ethnography. SAGE.

[74] Roger, K. S., \& Blomgren, C. (2019). Elicitation as a mind-set: Why visual data matter? International Journal of Qualitative Methods, 2(18), 19. https://doi.org/10.1177/1609406919835378

[75] Santos, J., Jesus, L. F. D., Sealmoy, R. R., \& Fajardo, R. R. C. (2021). Online distance learning amidst COVID-19. IJERI: International Journal of Educational Research and Innovation, 15, 291-304. https://doi.org/10.46661/ijeri.5271

[76] Schlesselman, L. S. (2020). Perspective from a teaching and learning center during emergency remote teaching. American Journal of Pharmaceutical Education, 84(8), 1042-1044. https://doi.org/10.5688/ajpe8142

[77] Sebbowa, D. K., \& Muyinda, P. B. (2018). The utilisation of a Mobile Phone Forum on the Winksite application in the teaching and learning of History: A case study of Pre-service Teachers at Makerere University. Yesterday and Today, 20, 124-147. https://doi.org/10.17159/22230386/2018/n19a6

[78] Senyshyn, R. M., Warford, M. K., \& Zhan, J. (2000). Issues of adjustment to higher education: International students' perspectives. International Education, 30(1), 17-35.

[79] Shim, T. E., \& Lee, S. Y. (2020). College students' experience of emergency remote teaching due to COVID-19. Children and Youth Services Review, 119, 105578. https://doi.org/10.1016/j.childyouth.2020.105578

[80] Singh, V., \& Thurman, A. (2019). How many ways can we define online learning? A systematic literature review of definitions of online learning (1988-2018). American Journal of Distance Education, 33(4), 289-306. https://doi.org/10.1080/08923647.2019.1663082

[81] Sintema, E. J. (2020). Effect of COVID-19 on the performance of grade 12 students: Implications for STEM education. Eurasia Journal of Mathematics, Science and Technology Education, 16(7), 1-6. https://doi.org/10.29333/ejmste/7893

[82] Slick, J. (2020). Coronavirus: When teaching during a disaster, students need to be partners. The Conversation. http://theconversation.com/coronavirus-when-teaching-during-a-disaster-students-need-to-be-partners-136695

[83] Smith, S. U. (2014). Frameworks Shaping an Online Professional Development Program for K-12 Teachers of ELLs: Toward Supporting the Sharing of Ideas for Empowering Classroom Teachers Online. TESOL Journal, 5(3), 444-464. https://doi.org/10.1002/tesj.154

[84] Sun, L., Tang, Y., \& Zuo, W. (2020). Coronavirus pushes education online. Nature Materials, 19(6), 687-687. https://doi.org/10.1038/s41563020-0678-8 
[85] Uztosun, M. S., Skinner, N., \& Cadorath, J. (2018). An action research study into the role of student negotiation in enhancing perceived student engagement during English speaking classes at university level in Turkey. Educational Action Research, 26(1), 106-126. https://doi.org/10.1080/09650792.2016.1270223

[86] Wang, M., Shen, R., Novak, D., \& Pan, X. (2009). The impact of mobile learning on students' learning behaviours and performance: Report from a large blended classroom. British Journal of Educational Technology, 40(4), 673-695. https://doi.org/10.1111/j.14678535.2008.00846.x

[87] Warschauer, M. (2004). Technology and social inclusion: Rethinking the digital divide. MIT Press.

[88] Wei, L. (2014). Peer teachers' online learning community for diversified college English teaching research: Cooperation and contribution. Theory and Practice in Language Studies, 4(3), 524-532. https://doi.org/10.4304/tpls.4.3.524-531

[89] Willis, J., \& Willis, D. (2013). Doing task-based teaching-Oxford handbooks for language teachers. Oxford University Press.

[90] Wong, J., \& Waring, H. Z. (2020). Conversation Analysis and Second Language Pedagogy: A Guide for ESL/EFL Teachers. Routledge. https://doi.org/10.4324/9780429488023

[91] Wong, L.-H., \& Hsu, C.-K. (2016). Effects of learning styles on learners' collaborative patterns in a mobile-assisted, Chinese characterforming game based on a flexible grouping approach. Technology, Pedagogy and Education, 25(1), 61-77. https://doi.org/10.1080/1475939X.2014.963661

[92] Xue, S., \& Churchill, D. (2020). Educational affordances of mobile social media for language teaching and learning: A Chinese teacher's perspective. Computer Assisted Language Learning, 1-30. https://doi.org/10.1080/09588221.2020.1765811

[93] Zayapragassarazan, Z. (2020). COVID-19: Strategies for online engagement of remote learners. F1000Research $2020,9(246), 1-11$. https://doi.org/10.7490/F100ORESEARCH.1117835.1 